College, Dublin; Dr. Vera Norris, senior statistical officer in the Department of Medical Statistics, on appointment as medical statistician at the Maudsley Hospital, University of London.

\section{Postgraduate Agricultural Scholarship Awards}

The Ministry of Agriculture and Fisheries has awarded postgraduate research and training scholarships in the following subjects, tenable in the first instance at the university or institute shown for periods up to three years from September 1, or later. Agricultural Economics : E. A. Attwood, School of Agriculture, Cambridge; and $\mathrm{K}$. C. Abercrombie, P. N. Barker, S. A. Bradburn, A. A. Marsh, J. D. Sykes and Miss F. R. Walker, Agricultural Economics Research Institute, Oxford. Agricultural Engineering: P. R. Attwood, D. P. Blight, D. J. B. Calverley, A. J. Crowther, J. L. Manson, W. T. B. Marchant, J. J. Thomas and M. A. Keech, King's College, Newcastle upon Tyne. Husbandry: A. J. Abbott, W. H. Broster, S. C. Meadowcroft, P. Radford, K. W. G. Shillam and Miss J. P. Tibbitts, University of Reading; D. Archer and R. J. Colley, University of Leeds ; B. F. Bland, A. W. Court, F. K. Deeble, B. C. Knight and R. P. Voelcker, School of Agriculture, Cambridge ; Miss D. E. Fisher, University of Nottingham; J. Sherwell and B. R. Watkin, Wye College, University of London; and J. G. Watkin Jones, Rowett Research Institute, Aberdeen. Agricultural Statistics : Miss A. W. Boyes, University of Oxford; and F. R. Latham, University of Manchester.

\section{Commonwealth Fund Fellowships for Study in the United States}

THE Commonwealth Fund of New York (41 East 57th Street, New York 22) is again offering a number of Commonwealth Fund fellowships to British subjects for study and travel in the United States. The fellowships provide for all expenses of travel, study and living, with some adjustment for married men with families. The fellowships, which are open to British men or women who are not normally resident in or near the Americas and who have not previously worked or studied for more than a few months in the United States, are offered annually in six categories as follows. Ordinary: twenty fellowships to graduates of a university in the United Kingdom of Great Britain and Northern Ireland. Candidates must be available in London for interview in March 1952 ; age, 23-35 ; tenure, 12-21 months ; applications by December 15. Home Civil Service : five fellowships to permanent members in the higher ranks of the Civil Service in Great Britain, three for the administrative grades and two for the scientific and professional grades. Age, less than 40; tenure, 6-12 months; applications by December 31 to the Treasury. Dominion Civil Service: five fellowships to Civil servants in the Governments of Australia, New Zealand and South Africa. Age, less than 40 ; tenure, 12-21 months; applications by February 1. Colonial Civil Service : two fellowships to Civil servants in the Governments of the British Colonies, Protectorates, and Trust Territories. Age, less than 40; tenure, 12-21 months; applications by December 31 to the Colonial Office, London. Journalism: three fellowships to journalists practising in the United Kingdom and engaged on the opinion-making or broadly editorial side of their profession. Age, 23-35 ; tenure, 9-15 months; applications by January 1, 1952. American Studies : four fellowships will be available to faculty members appointed to or holding posts in
American studies in universities in the United Kingdom, candidates to be nominated by their universities; tenure, 4-12 months; these fellowships are not limited by previous study in the United States. Application forms and further details of these fellowships can be obtained through British universities or through government departments, or from the Warden, Harkness House, 35 Portman Square, London, W.1.

\section{Announcements}

H.R.H. the Duke of Fdinburgh has been elected an hororary member of the British Institution of Radio Engineers.

THE Franklin Medal, the highest honour given by the Franklin Institute, Philadelphia, has been awarded to Sir James Chadwick, master of Gonville and Caius College, Cambridge, for his work in nuclear physics.

Prof. P. Th. Oosterhoff, Sterrewacht, Leyden, has been appointed assistant general secretary of the International Astronomical Union. Prof. Bengt Strömgren remains general secretary of the Union.

The Committee of the Privy Council for Agricultural Research and Nature Conservation has reappointed Sir Alan Drury, Director of the Lister Institute, to the Agricultural Research Council for a further term, and has also appointed Prof. S. J. Watson, professor of agriculture and rural economy in the University of Edinburgh, to fill the vacancy caused by the retirement from the Council, on completion of his term of office, of Prof. T. J. Mackie.

THE following appointments have been announced from the University of London: Dr. Ruth Bowden, to the University chair of anatomy tenable at the Royal Free Hospital School of Medicine; Dr. R. J. Harrison, to be head of the Department of Anatomy at the London Hospital Medical College, with the title of reader in anatomy in the University in respect of this post.

THE Société Française de Métallurgie will be holding a series of autumn sessions during October 22-27 at the Centre Marcelin Berthelot, Maison de la Chimie, 28bis rue St. Dominique, Paris $7 \mathrm{e}$. On each day papers will be read on a number of metallurgical topics. Further details can be obtained from the Society at 5 Cité Pigalle, Paris 9e.

THE British Standards Institution has recently published "Methods for the Analysis of Soaps" (B.S. 1715: 1951. Pp. 42; London: British Standards Institution, $1951 ; 5 s$. net). This document gives both the British Standard methods and also the methods of the International Commission for the study of fats. Full details of the analytical methods and of any special apparatus required are outlined.

THReE textile research fellowships have been created by the Commonwealth Scientific and Industrial Research Organization to enable research men trained in physics, chemistry or engineering to obtain special experience in textile science in the United Kingdom. The fellowships are being financed from money made available by the Associated Woollen and Worsted Textile Manufacturers of Australia. Fellows will be appointed for twelve months. They will receive a salary of $£ A 1,000$ per annum, plus travelling expenses. Further details can be obtained from the Secretary, C.S.I.R.O., 314 Albert Street, East Melbourne. 